$4.39 \log ^{10} \mathrm{IU} / \mathrm{ml}, 93.3 \mathrm{mmol} / 1$ and $44.9 \mathrm{mmol} / 1$ respectively, versus $5.10 \log ^{10} \mathrm{IU} / \mathrm{ml}, 34 \mathrm{mmol} / \mathrm{l}$ and $47 \mathrm{mmol} / \mathrm{l}$ in treatment naïve patients. In treatment experienced patients prescribed entecavir $(n=6)$ the mean HepB DNA, ALT and albumin levels at baseline were; $2.01 \log ^{10} \mathrm{IU} / \mathrm{ml}, 26.6 \mathrm{mmol} / 1$ and $47.2 \mathrm{mmol} / 1$ respectively, versus $6.12 \log ^{10} \mathrm{IU} / \mathrm{ml}, 107.2 \mathrm{mmol} / 1$ and 43.8 in treatment naïve patients. Overall there was no difference $(p=0.83)$ in the mean time to undetectable viral load in patients treated with tenofovir ( $\mathrm{n}=26$, mean 5.19 ) versus entecavir ( $\mathrm{n}=34$, mean 6.18 months); including when subdivided into HepBeAg-positive $(p=0.87)$ and HepBeAg-negative $(p=0.80)$ groups. Improvement in synthetic function was observed following treatment with both agents in cirrhotic patients.

Conclusion Viral load reduction to undetectable levels was observed in patients treated with either tenofovir or entecavir within 12 months with equivalent efficacy. The data suggest that either agent may be used in the management of CHB in both treatment experienced and naïve patients. However, the role of baseline resistance profiling in treatment naïve patients started on entecavir remains to be established.

Competing interests None.

Keywords entecavir, hepatitis B, tenofovir.

\title{
REFERENCE
}

1. Woo G, et al. Gastroenterology 2010;139:1218-29.

\section{PTH-075 LONG TERM EXPERIENCE USING TENOFOVIR AND ENTECAVIR IN THE MANAGEMENT OF CHRONIC HEPATITIS B IN TEACHING HOSPITAL PRACTICE}

doi:10.1136/gut.2011.239301.476

PA Blaker, ${ }^{1,}{ }^{*}$ L Lee, ${ }^{1}$ A Ali, ${ }^{2}$ M L Wilkinson, ${ }^{1}$ T Wong ${ }^{1}$ 'Department of Gastroenterology, Guy's and St Thomas' Hospital, London, UK; '2Department of Pharmacy, Guy's and St Thomas' Hospital, London, UK

Introduction In the first 12 months of treatment for chronic hepatitis $\mathrm{B}(\mathrm{CHB})$ infection tenofovir and entecavir have been reported as the most potent antiviral agents for HepBeAgpositive patients; tenofovir is the most effective for HepBeAgnegative patients. ${ }^{1}$ However, the long-term outcome of patients treated with these agents remains unclear. The authors report our teaching hospital experience of tenofovir and entecavir in the treatment of $\mathrm{CHB}$.

Methods All patients $(n=112)$ treated for CHB between 2005 and 2010 with tenofovir $(n=53)$ or entecavir $(n=59)$ were identified from a pharmacy database and included in a retrospective audit. Levels of HepB DNA, ALT and albumin were collected at baseline and on a 3 monthly basis for the first 12 months and 6 monthly thereafter. The maximum duration of treatment was 48 months.

Results Of patients receiving tenofovir 38\% were $\mathrm{HepBeAg-}$ positive and $15 \%$ were cirrhotic versus $49 \%$ and $17 \%$ respectively in those treated with entecavir. Two patients in the tenofovir cohort seroconverted to e-antigen negative. The authors observed one case of early virological rebound (at week 27 ) in a treatment naive patient prescribed entecavir through selection of lamivudine-associated mutations. The mean duration of treatment with tenofovir was 11 months $(\mathrm{SD} \pm 7.8$, range $3-48)$ versus 15 months ( $\mathrm{SD} \pm 9.4$, range $0-30)$ for entecavir. In treatment experienced patients receiving tenofovir $(n=35)$ the mean HepB DNA, ALT and albumin levels at baseline were; 